Research article

\title{
How to reconcile wood production and biodiversity conservation? The Pan-European boreal forest history gradient as an "experiment"
}

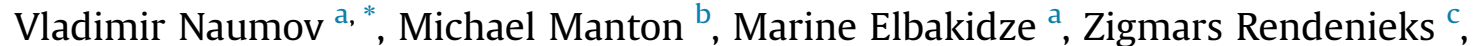 \\ Janis Priednieks ${ }^{\mathrm{d}}$, Siarhei Uhlianets ${ }^{\mathrm{e}}$, Taras Yamelynets ${ }^{\mathrm{f}}$, Anton Zhivotov ${ }^{\mathrm{g}}$, \\ Per Angelstam ${ }^{\text {a }}$ \\ a Swedish University of Agricultural Sciences, School for Forest Management, PO Box 43, SE-73921 Skinnskatteberg, Sweden \\ b Aleksandras Stulginskis University, Institute of Forest Biology and Silviculture, Studentu g.11, Akademija, LT-53361 Kauno r., Lithuania \\ c University of Latvia, Faculty of Geography and Earth Sciences, Jelgavas iela 1, Riga, LV-1004, Latvia \\ ${ }^{\mathrm{d}}$ University of Latvia, Faculty of Biology, Jelgavas iela 1, Riga, LV-1004, Latvia \\ e V.F Kuprevich Institute of Experimental Botany, 27 Akademichnaya Street, Minsk 220072, Belarus \\ f Ivan Franko National University, Faculty of Geography, 41 Doroshenko Street, 79000 Lviv, Ukraine \\ ${ }^{g}$ Pskovlesproekt Company, Shkolnaya Street 6, 18006 Pskov, Russian Federation
}

\section{A R T I C L E I N F O}

Article history:

Received 14 September 2017

Received in revised form

20 March 2018

Accepted 22 March 2018

\section{Keywords:}

Bio-economy

Conservation

Forest policy

Intensification

Land-sharing

Land-sparing

Spatial planning

Sustainable forest management

\begin{abstract}
A B S T R A C T
There are currently competing demands on Europe's forests and the finite resources and services that they can offer. Forestry intensification that aims at mitigating climate change and biodiversity conservation is one example. Whether or not these two objectives compete can be evaluated by comparative studies of forest landscapes with different histories. We test the hypothesis that indicators of wood production and biodiversity conservation are inversely related in a gradient of long to short forestry intensification histories. Forest management data containing stand age, volume and tree species were used to model the opportunity for wood production and biodiversity conservation in five north European forest regions representing a gradient in landscape history from very long in the West and short in the East. Wood production indicators captured the supply of coniferous wood and total biomass, as well as current accessibility by transport infrastructure. Biodiversity conservation indicators were based on modelling habitat network functionality for focal bird species dependent on different combinations of stand age and tree species composition representing naturally dynamic forests. In each region we randomly sampled 25 individual $100-\mathrm{km}^{2}$ areas with contiguous forest cover. Regarding wood production, Sweden's Bergslagen region had the largest areas of coniferous wood, followed by Vitebsk in Belarus and Zemgale in Latvia. NW Russia's case study regions in Pskov and Komi had the lowest values, except for the biomass indicator. The addition of forest accessibility for transportation made the Belarusian and Swedish study region most suitable for wood and biomass production, followed by Latvia and two study regions in NW Russian. Regarding biodiversity conservation, the overall rank among regions was opposite. Mixed and deciduous habitats were functional in Russia, Belarus and Latvia. Old Scots pine and Norway spruce habitats were only functional in Komi. Thus, different regional forest histories provide different challenges in terms of satisfying both wood production and biodiversity conservation objectives in a forest management unit. These regional differences in northern Europe create opportunities for exchanging experiences among different regional contexts about how to achieve both objectives. We discuss this in the context of land-sharing versus land-sparing.
\end{abstract}

(c) 2018 Elsevier Ltd. All rights reserved.

\footnotetext{
* Corresponding author.

E-mail address: vladimir.v.naumov@gmail.com (V. Naumov).
}

\section{Introduction}

Traditional European forest management aims to maximize economic revenue from forest resources such as timber, pulpwood and biomass (Puettmann et al., 2009). However, current policies about sustainable forest management also target the maintenance 
of other benefits, such as biodiversity and social values (European Forest Institute, 2013; The Montreal process, 2015). This is consistent with green infrastructure policy for natural and semi-natural land covers in general (European Commission, 2013). There are, however, currently new emerging conflicts between competing demands on Europe's forests and the finite resources and services that they can offer (EASAC, 2017). Several international agreements and policy areas have impact on EU forests, such as the Paris Agreement on climate change which is used to advocate that intensified forest management helps mitigate climate change, and the Convention on Biological Diversity. This is particularly evident from the emerging focus on bio-economy as a means of advocacy towards intensifying the traditional wood and biomass production (EASAC, 2017). Supported by powerful actors this discourse may displace policy about sustainable forest management and biodiversity conservation (e.g., Pülzl et al., 2014).

Whether or not forestry intensification and biodiversity conservation are rival can be understood by comparative studies of forest landscapes with different histories (Angelstam et al., 2018). The past trajectories of forest use and management in a particular region may affect the opportunities for delivering present and future benefits in terms of forest landscapes' goods, services and values (Worster, 1994; Balee, 2002; Williams, 2003). To understand the role of regional context for satisfying production and conservation objectives, a landscape history approach has been used in Sweden (Angelstam et al., 2013a), Latvia (Susko, 1997), Belarus (Gusev, 2014) and Russia (Josephson et al., 2013; Naumov et al., 2016).

Northern Europe, including Fennoscandia, the Baltic States, Belarus and NW Russia, hosts a diverse range of forest landscape histories along the West-East gradient from markets demanding natural resources to regions that deliver them (Angelstam et al., 2011a, 2013b). This led to expanding frontiers of forest resource demands, and as a response, efforts to intensify wood production. For example, in Sweden and Finland methods for intensive wood production have been implemented (Sverdrup and Stjernquist, 2013; Nordberg et al., 2013). The same process is in progress in the Baltic States (Tērauds et al., 2011; Angelstam et al., 2018) with forest management aiming to secure financial income for state companies and private enterprises by adopting the Fennoscandian model towards intensification (Vanwambeke et al., 2012; Brukas, 2015; Rendenieks et al., 2015a). Increased wood production is also promoted in Belarus by including all economically accessible and non-protected areas into wood production (Anonymous, 2010). In contrast, Russia has only recently commenced discussions on the opportunities for intensified wood production. Nevertheless, some localized actions have been tested on the ground (Naumov et al., 2016). These efforts have been hampered and largely unsuccessful due to a poorly developed road network (Holopainen et al., 2006; Goltsev et al., 2012) as well as societal and institutional obstacles (Angelstam et al., 2017a). There is thus a West-East gradient in the implementation of forestry intensification.

Conversely, where intensification of wood and biomass production has been successful, biodiversity conservation and restoration has become a difficult challenge (Halme et al., 2013; Angelstam et al., 2018). In northern Europe's West (e.g., Sweden) intensification of forest management continues, and the current biodiversity conservation challenge remains (Angelstam et al., 2011b; Jonsson et al., 2016). Thus, countries in the West have not maintained the historical range of variability of boreal and hemiboreal forests (Kuuluvainen, 2002). To maintain biodiversity in terms of species, habitats and processes (Brumelis et al., 2011), efforts towards protection of high conservation value forests (Angelstam et al., 2011b), conservation management (Angelstam et al., 2017b; Similiä and Junninen, 2012; Stanturf, 2015) and landscape restoration (Miller and Hobbs, 2007; Dawson et al., 2017) are being made. Also, the Baltic States aim at maintaining remnants of near-natural forest ecosystems (Kurlavicius et al., 2004). In NW Russia's remote regions with a short history of forest use (Moiseev, 2001), Europe's last intact forest massifs still exist (Aksenov et al., 2002). However, they are facing increasing pressure as forestry is recovering after the collapse of the Soviet Union (Brukas, 2015; Naumov et al., 2017).

This diversity of contexts implies that the overall goal of sustainable forest management needs to be approached from different directions in Europe's West and East, respectively. Hence, there is a need to understand how to satisfy the objectives of both wood production and biodiversity conservation in different forest landscape history and societal contexts at multiple spatial scales (Angelstam et al., 1995, 2018). At the European level there is a debate whether to integrate production and biodiversity goals at the stand level, or to segregate them at the landscape level (Bollmann and Braunisch, 2013). However, there is a lack of comparative studies on how these two goals can be integrated at the scale of forest management units in different forest history and societal contexts in Europe.

The aim of this paper is to compare the potentials for satisfying both wood production and biodiversity conservation objectives in boreal Europe's West and East, which have different forest landscape histories and societal contexts. We developed and applied indicators for wood production and for biodiversity conservation in regions that represent different trajectories of forest resource use and management in Sweden, Latvia, Belarus and NW Russia. These countries are members of the Pan-European process on criteria and indicators for sustainable forest management (http://www.fao.org/ forestry/ci/16609@45898/en/). Using four indicators for wood production and four indicators for biodiversity conservation, we tested the hypothesis that wood production and biodiversity conservation are rival objectives. We discuss the opportunities for land-sparing by zoning at different spatial scales to accommodate competing forest benefits in forest management units in societal contexts with different types of land ownership and landscape stewardship.

\section{Methodology}

\subsection{The regional logging frontier in the northern Europe as an experiment}

The spatial extent of entire forest management units, or simply local landscapes, located in regions with different land use histories precludes the application of replicated experiments. An alternative option is natural experiments (sensu Diamond, 1986) in the form of comparative macroecological studies that trade off the precision of small-scale research with an appropriate spatial scale (Brown, 1995). To capture the gradient in forest use history in northern part of the European continent we selected five case study regions located in Sweden (Bergslagen), Latvia (Zemgale), Belarus (Vitebsk) and NW Russia (Pskov and Komi) where the logging frontier swept from the West to the East over the past two centuries (Naumov et al., 2017). The dominating tree species are Norway spruce (Picea abies), Scots pine (Pinus sylvestris) and deciduous trees (Betula spp., Populus tremula). In both North America and Europe, the terms logging frontier and timber frontier (Drushka, 2003) describe spatially expanding large-scale extensive logging of trees without regeneration efforts ("wood mining"). For instance, in Sweden the frontier of industrial harvesting began regionally in south-central Sweden's metallurgic industry region Bergslagen 
(Angelstam et al., 2015) and spread northwards from the mid-19th century (Östlund et al., 1997). High-grading methods dominated at first, i.e. only valuable and big trees were cut. The same approach occurred locally in European Russia in the 18-19th centuries (Red'ko and Babych, 1993; Moiseev, 2001). Since the mid-19th century Sweden's once naturally dynamic forests have been transformed to even-aged forest stands aimed at maximum sustained yield forestry (Östlund et al., 1997), whereas in NW Russia intact forest landscapes remain (Aksenov et al., 2002). In Latvia and Belarus forest exploitation for timber began later compared to Western Europe (Tērauds et al., 2011). We used the forest use history gradient from Sweden via Latvia and Belarus to NW Russia to compare forest regions which have completed $4-5$ forest rotations in the West (Angelstam et al., 2011a) to not yet one full forest rotation in the East (Naumov et al., 2016).

In each of the five case study regions, we randomly selected 25 individual $100-\mathrm{km}^{2}$ grid cells with $>40 \%$ forest cover for analyses, viewing those as local forest management units. This area corresponds to the order of magnitude of forest landscape planning units in the Baltic Sea Region, which are typically $50-300 \mathrm{~km}^{2}$ (Elbakidze et al., 2016; Angelstam et al., 2017a). The 40\% forest cover threshold corresponds to the requirement of species sensitive to forest fragmentation by allowing percolation of individuals through contiguous habitat (Gardner et al., 1991; With and Crist, 1995).

\subsubsection{Bergslagen region in Sweden}

The informal Bergslagen region (hereafter SE-Bergslagen) (Fig. 1) in south-central Sweden is a good example of a region with a long history of focusing on maximum sustained yield forestry for wood production (Angelstam et al., 2015). The bedrock is rich in minerals (Stephens et al., 2009), and metals were first produced there already more than 2000 years ago (Nelson, 1913). Mining and metal production led to intensive use of forests to produce charcoal, and thus gradually to maximum sustained yield forestry. To secure contiguous forest stand data in the core of SEBergslagen we chose to use the forest management data for the state forest company Sveaskog (Elbakidze et al., 2013). Formally protected areas and voluntary set-asides occupy $10.4 \%$ of total forest land area (Elbakidze et al., 2010). Total forest cover in the 25 different $100-\mathrm{km} 2$ grid cells selected in SE-Bergslagen was high (75\%) and was dominated by Scots pine and Norway spruce. Mires made up $8.6 \%$, freshwater bodies $8.9 \%$ and agricultural land $7.2 \%$ (Table 1).

\subsubsection{Zemgale planning region in Latvia}

The Zemgale planning region (LV-Zemgale, $10,733 \mathrm{~km}^{2}$ ) is located in southern Latvia along the border with Lithuania (Fig. 1). The forest history of forest management in LV-Zemgale is complex (e.g., Fescenko et al., 2014). During the Soviet period (1940-1991) forestry was an industry of secondary importance. After the Soviet period from 1991 Latvian forestry actively adopted a marketoriented forest management approach and signed agreements promoting sustainable management of forests (Têrauds et al., 2011; Rendenieks et al., 2015a). Being important for the country's economy, forest harvesting rates have increased over the past two decades. A total of $50 \%$ of forest is owned by the state. The rest is owned by several private industrial companies and numerous small non-industrial private forest owners. The dominating land covers of the 25 different $100-\mathrm{km} 2$ areas selected in LV-Zemgale included a mixture of forest (84\%), agricultural land (10\%) followed by mires $3 \%$, and freshwater bodies (1\%) (Table 1 ).

\subsubsection{Vitebsk oblast in Belarus}

The study region in NW Belarus (hereafter BY-Vitebsk,
$9102 \mathrm{~km}^{2}$ ) includes 5 municipalities (Fig. 1) located in the Vitebsk oblast in NW Belarus. Belarus keeps legacies from the Soviet period of forest management. Thus, forests remain as state property, and all silviculture and logging activities are done by state enterprises. After collapse of the Soviet Union in 1991, forest harvesting decreased, but by the end of the 2000s had returned to its previous level (Fedorenchik, 2014). The dominating land covers of the 25 different $100-\mathrm{km} 2$ areas selected in BY-Belarus included forest (79\%), agricultural land (10\%) followed by mires (9\%), and freshwater bodies (9\%) (Table 1). BY-Vitebsk includes 5 municipalities in the western part of that oblast.

\subsubsection{Pskov oblast in NW Russia}

Pskov oblast is the westernmost administrative subject of the contiguous Russian Federation and covers $5625 \mathrm{~km}^{2}$ (RU-Pskov). Dominating tree species include Norway spruce, Scots pine, aspen, and birch species. Reforestation after harvesting started only in the 1960s. Since the collapse of Soviet Union, the rural population has dwindled, and many fields and meadows have been abandoned. During the latter half of the 1990s commercial wood harvesting was increased again, mainly for bioenergy but also some conifers for sawmilling. The main land covers of the 25 different $100-\mathrm{km}^{2}$ areas selected in RU-Pskov included forest (73\%), agricultural fields (18\%) followed by mires (5\%) and freshwater bodies (1\%) (Table 1 ).

\subsubsection{Komi Republic in NW Russia}

The Komi Republic in NW Russia (RU-Komi) has the shortest forest history (Fig. 1). We used data from the Kortkeros district $\left(2477 \mathrm{~km}^{2}\right)$ where the frontier of final felling of old-growth forest reached the area in the 1960s, and currently forests are either younger successional stages or remnants of naturally dynamic oldgrowth forests (Naumov et al., 2016). The Kortkeros district plays a key role in the Komi Republic's forestry and is among the most exploited forest areas at regional level (Sherstyokova, 2012). All forest land is state-owned. The 25 different $100-\mathrm{km} 2$ areas selected in Kortkeros were dominated by forest ( $81 \%$ ), mires cover $4 \%$ while agricultural fields and water bodies total only $0.1 \%$ (Table 1 ).

\subsection{Harmonization of spatial data}

To assess the opportunity of satisfying wood production and biodiversity conservation objectives at the forest management unit level, using 25 different $100-\mathrm{km}^{2}$ areas as proxies for each study region, we used digital spatial forest management databases describing stand age, tree species and area. The spatial databases represented the time period 1994-2010. This small variation should be compared to the broad range of time periods that the five different forest regions have been subject to intensive forest management aimed at maximum sustained yield forestry, i.e. $>150$ years for SE-Bergslagen, $<30$ years in LV-Zemgale and BY-Vitebsk, and not at all in RU-Pskov and RU-Komi. To minimize spatial data distortions, each regional dataset was individually analyzed using the local coordinate system.

Indicators of wood production and biodiversity conservation states were based on spatial modelling. The variables and parameter values for indicators included both direct data, e.g. land cover, and proxy data such as distance to transport infrastructure. For each of the $100-\mathrm{km}^{2}$ grid cells we calculated the total area proportion of the forest mask that satisfied each of the four wood production and four biodiversity conservation indicators. Since our indicator variables are proportions (e.g., coniferous stands proportion of total forested area within $100 \mathrm{~km}^{2}$ grid cells), we employed generalized linear models with binomial errors of response variable and logit link function (Fox, 2015) to test if these indicators are the same across 5 study regions. To account for over- 


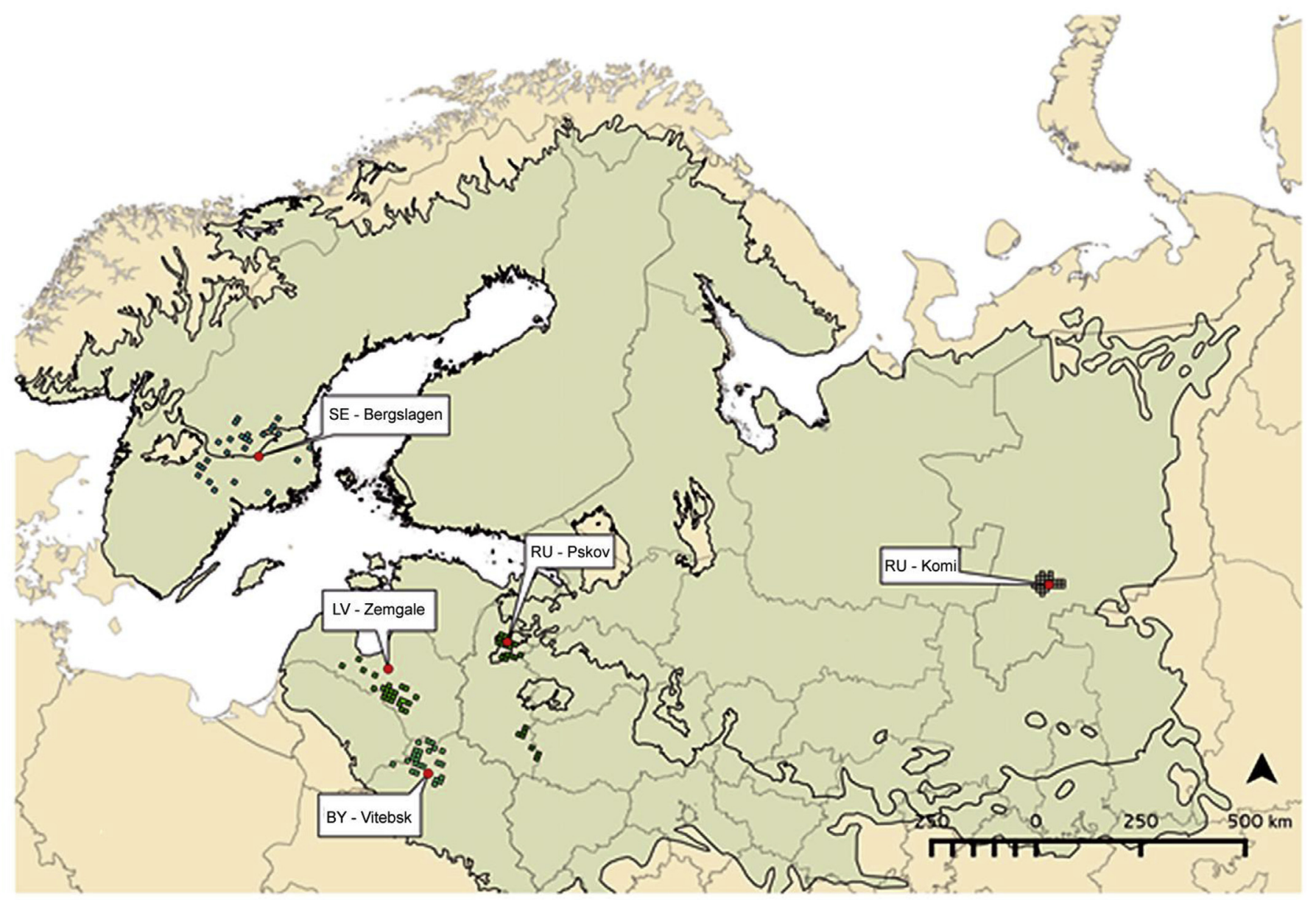

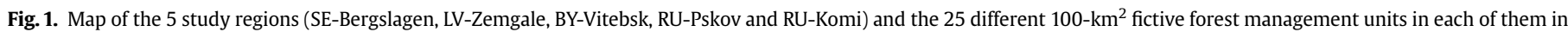
northern Europe. Hatched area represents boreal and hemi-boreal biomes. Source: OpenStreetMap contributors (www.openstreetmap.org).

dispersion (Hinde and Demétrio, 1998) we refitted the models using quasi-binomial family of errors.

\subsection{Wood production indicators}

\subsubsection{Coniferous wood (CONWOOD)}

The minimum accepted final-felling age was determined using the dominating forest site type quality represented in the Swedish case study (SE-Bergslagen) for Scots pine and Norway spruce, i.e. the two conifer species in focus, for maximum sustained yield forestry in northern Europe. The suitable site type quality for Scots pine and Norway spruce respectively were T24 and G28, (i.e. according to the Swedish $\mathrm{H} 100$ system in which site type quality is defined as a combination of a tree species codes ( $T$ for pine and $G$ for spruce) and the tree height at age 100 years) (Skogsstyrelsen, 2013), and set to minimum age of 65 years (Table 2)). This is the norm for maximum sustained yield forestry and mirrors the intensification ambitions of the countries studied. The standing volume threshold was set to the average at the age 65 years ( 250 $\mathrm{m}^{3} / \mathrm{ha}$ ) in the core of SE-Bergslagen. The area of selected stands was expressed as the proportion of the forest mask inside each $100-\mathrm{km}^{2}$ grid cell. The forest mask includes all forest stand age classes, including clear-cuts. Stands were included based on the defined variables and their parameter values (Table 1).

\subsubsection{Bioenergy (BIOMASS)}

Biomass from forests is an increasingly important commodity for bioenergy production (Parikka, 2004). This includes fuelwood, other biomass, charcoal and black liquor (Trossero and Drigo, 2004). Focusing on direct forest products we defined biomass (BIOMASS) as timber, pulpwood and biomass. To maximize forest harvest for biomass production we assumed that all tree species are

Table 1

Descriptive statistics of land cover proportions in 25 individual $100-\mathrm{km}^{2}$ cells used as proxies for local forest management units.

\begin{tabular}{|c|c|c|c|c|c|c|}
\hline Country & Study area definition & $\begin{array}{l}\text { Size of forest } \\
\text { management unit (ha) }\end{array}$ & Forest (\%) & Agricultural fields (\%) & Mires (\%) & $\begin{array}{l}\text { Freshwater } \\
\text { bodies (\%) }\end{array}$ \\
\hline Sweden (SE-Bergslagen) & Sveaskog Co in Bergslagen region & 567,614 & $74.9(51.4-85.2)$ & $7.2(0.4-25.5)$ & $8.6(1.6-21.6)$ & $8.9(0.3-28.0)$ \\
\hline Latvia (LV-Zemgale) & Zemgale planning region & 420,758 & $84.1(62.4-99.6)$ & $9.5(0.4-16.7)$ & $2.5(0.0-9.0)$ & $1.4(0.1-3.6)$ \\
\hline Belarus (BY-Vitebsk) & $\begin{array}{l}\text { Braslav, Grubok, Mior, Postav and } \\
\text { Sharkoy districts }\end{array}$ & 910,191 & $79(51.2-87.7)$ & $9.5(1.0-20.3)$ & $9.0(1.4-15.5)$ & $8.9(0.2-30.0)$ \\
\hline Russia (RU-Pskov) & $\begin{array}{l}\text { Strugo-Krasny, Velikoluky and Kunyisk } \\
\text { districts in Pskov oblast }\end{array}$ & 562,500 & $73.1(54.8-87.2)$ & $18.3(4.6-36.7)$ & $4.9(0.1-20.5)$ & $1.2(0.0-11.1)$ \\
\hline Russia (RU-Komi) & Kortkeros district in Komi Republic & 247,692 & $81.3(54.5-99.4)$ & $0.1(0.0-0.4)$ & $3.9(0.0-29.9)$ & $0.1(0.0-0.2)$ \\
\hline
\end{tabular}


Table 2

Variables and target values for wood production indicators estimated for each forest stand in local $100-\mathrm{km}^{2}$ cells used as proxies for local forest management units.

\begin{tabular}{|c|c|c|c|}
\hline Indicators & Variables used for modelling & Unit & Parameter values \\
\hline \multirow[t]{4}{*}{ Sawlogs and pulpwood (CONWOOD) } & Tree species & $\mathrm{NA}\left({ }^{*}\right)$ & Scots pine OR Norway spruce \\
\hline & Proportion & $\%$ & $>=70$ \\
\hline & Age & years & $>=65$ \\
\hline & Standing volume & cubic $\mathrm{m} / \mathrm{ha}$ & $>=250$ \\
\hline \multirow[t]{3}{*}{ Forest biomass for energy (BIOMASS) } & Tree species & NA & NA \\
\hline & Share & $\%$ & $1-100$ \\
\hline & Standing volume & cubic $\mathrm{m} / \mathrm{ha}$ & $>=100$ \\
\hline \multirow[t]{2}{*}{ Accessible forest biomass (ACC_BIO) } & BIOMASS & ha & NA \\
\hline & Location from road & $\mathrm{m}$ & $<=500$ \\
\hline \multirow[t]{2}{*}{ Accessible sawlogs and pulpwood (ACC_CON) } & CONWOOD & ha & NA \\
\hline & Location from road & $\mathrm{m}$ & $<=500$ \\
\hline
\end{tabular}

$\left({ }^{*}\right)$ NA - not applicable, no threshold is applied.

equally useful. In Finland, Ahtikoski et al. (2008) estimated that a harvest level of about $45-60 \mathrm{~m}^{3} /$ ha is economically viable. Thus, we assumed that the stand volume should be $>100 \mathrm{~m}^{3} /$ ha to satisfy sufficient economic net benefits (Table 2). The algorithm of spatial and statistical operations was the same as for CONWOOD.

\subsubsection{Accessible coniferous wood (ACC_CON) and biomass (ACC_BIO)}

To be economically effective, accessibility of wood and biomass was assigned based on a 500-m buffer into the forest from forest roads, represented by economically acceptable forwarding costs (Nordfjell et al., 2003). This was done by masking stands selected for indicators CONWOOD and BIOMASS with a 500-m buffer from roads (Table 2). The algorithm of spatial and statistical operations was the same as for CONWOOD.

\subsection{Biodiversity conservation indicators}

\subsubsection{Habitat suitability index models using knowledge about focal species}

The amount of functional habitat network for species, i.e. one of the aims of green infrastructure (European Commission, 2013), is a key variable affecting the opportunity for biodiversity conservation (Lindenmayer and Franklin, 2002). To maintain viable species populations, it is vital and efficient to consider the requirements of focal species, and to identify priority areas for conservation across entire landscapes (Woodhouse et al., 2000). The focal species approach (Lambeck, 1997) is based on the idea that conservation of specialized and area-demanding species can contribute to the protection of many naturally co-occurring species (Hess and King, 2002; Roberge and Angelstam, 2004). This can be viewed as an umbrella function based on the assumption that the maintenance or restoration of habitats with the quantities and qualities for the most demanding species will meet also the requirements of other species dependent on the same or similar habitats (Roberge and Angelstam, 2004). The protection and active management of sufficiently connected and functional habitat networks for focal species is therefore likely to accommodate also less demanding species in viable populations (Margules and Pressey, 2000; Gergle and Turner, 2001).

Combining the focal species approach and habitat suitability index (HSI) modelling (Scott et al., 2002) can assist operational planning in the quest towards maintaining biodiversity (Angelstam et al., 2003; Gibson et al., 2004; Manton et al., 2005). HSI models combine empirical data knowledge about focal species' habitat requirements using variables and parameter values for land covers, digital land cover data and a geographic information system (GIS) to run ecologically relevant algorithms (Kliskey et al., 1999). The creation of HSI models involves three main steps. Firstly, the suitable forest land covers, for example a certain forest type with a certain age class and tree species structure, as required by the target focal species, is selected. Secondly, the patches satisfying the minimum areas required by the target focal species are selected. The final step involves identifying suitable forest habitat tracts where the species-specific critical thresholds at the local landscape level are satisfied (Angelstam et al., 2004). Technically this can be produced by applying a neighborhood window analysis (Manton et al., 2005) based on the home range size of the targeted focal species, thus providing a key indication of the species-specific connectivity of land cover stands at the landscape scale (Villard and Taylor, 1994; Fahrig, 2003). The resulting probability map is then used to estimate the area proportion of available habitat among the 25 randomly selected $100 \mathrm{~km}^{2}$ grid cells.

Birds are often used as indicators of biodiversity at larger spatial extents (Newey et al., 2016). To estimate biodiversity conservation indicator values, with focus on the most abundant representative habitats in naturally dynamic forest landscapes, we selected a suite of area-demanding resident focal forest bird species that match different combinations of deciduous and coniferous proportions in different stand age classes (Fig. 2, Table 3). The selected species are vulnerable to maximum sustained yield wood production because intensive forestry reduces both the deciduous component in young and middle-aged stands, and the amount of dead wood in late successional stages (Angelstam et al., 2004). Obviously, forestry intensification alters many more aspects of biodiversity than can be captured by spatial modelling using forest birds as focal species. For instance, Ranius and Roberge (2011) showed that intensified forestry leads to strongly increased extinction risks of all saproxylic insect species. Thus, they can be used as indicators of habitat quality (Djupström et al., 2012). Nevertheless, birds have advantages as well-studied focal species for which the habitat requirements are better documented than for other specialized organisms (Angelstam et al., 2004). Moreover, there is a trade-off between attempting to capture aspects of biodiversity in great detail, i.e. species, habitats and processes (Brumelis et al., 2011) on the one hand, and comprehensible communication of the results to stakeholders, planners and policy makers on the other. Birds are usually better recognized by forest land owners than other species, such as lichens or vascular plants (Uliczka et al., 2004).

\subsubsection{Old pine forest (PINE)}

The capercaillie (Tetrao urogallus) is an area-demanding old pine forest specialist (Storch, 1997). The forest usually has bilberry (Vaccinium myrtillus) as ground vegetation (Hjeljord et al., 2000; Angelstam et al., 2004). At the landscape scale a critical threshold minimum of $25 \%$ suitable habitat in a $16 \mathrm{~km}^{2}$ area (Table 3 ) is sufficient for presence of a local population (Angelstam, 2004). Thus, capercaillie can be used as focal species in boreal forests (Suter et al., 2002; Pakkala et al., 2003). 


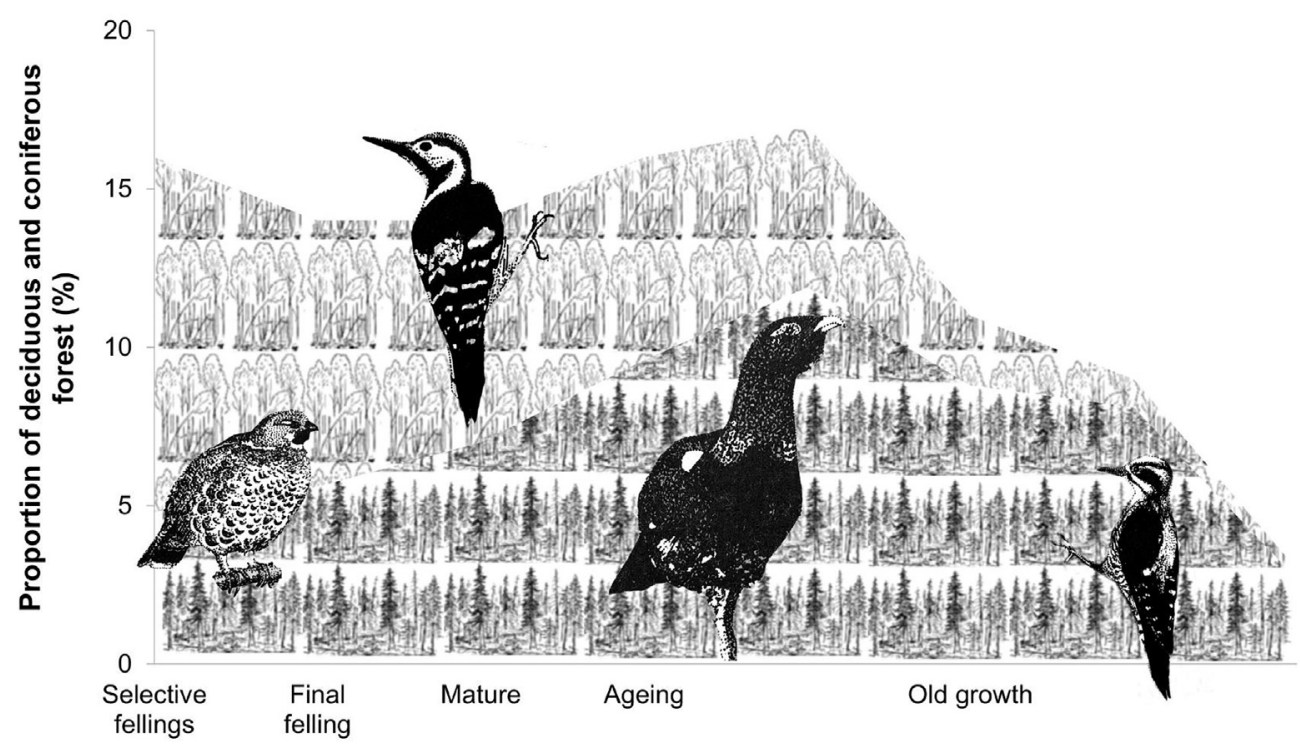

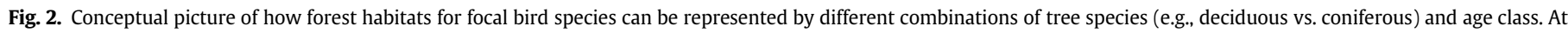

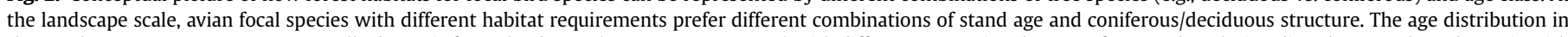

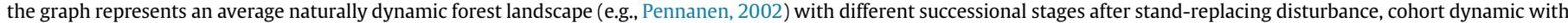
Scots pine and gap phase dynamic with Norway spruce (Angelstam and Kuuluvainen, 2004). Bird drawings by Maris Stradz.

Table 3

Variables and target values for biodiversity indicators estimated for each forest stand in local $100-\mathrm{km}^{2}$ cells used as proxies for local forest management units.

\begin{tabular}{|c|c|c|c|c|c|c|}
\hline \multirow{2}{*}{$\begin{array}{l}\text { Forest habitat types not } \\
\text { accommodated by maximum } \\
\text { sustained yield forestry }\end{array}$} & \multirow[t]{2}{*}{ Focal species } & \multicolumn{5}{|c|}{ Variables and its parameter values } \\
\hline & & Tree species & Propor-tion (\%) & Age (years) & $\begin{array}{l}\text { Patch size } \\
\text { requirements } \\
\text { (ha) }+ \text { buffer }(\mathrm{m})\end{array}$ & $\begin{array}{l}\text { Neighborhood window } \\
\text { size }\left(\mathrm{km}^{2}\right) \text { and minimum threshold (\%) }\end{array}$ \\
\hline Old pine (PINE) & Capercaillie & Scots pine & $>=70$ & $>=70$ & 200 & $16(25)$ \\
\hline Old spruce (SPRUCE) & Three-toed woodpecker & Norway spruce & $>=50$ & $>=80$ & $10+25$ & $4(25)$ \\
\hline Deciduous successions (DEC) & White-backed woodpecker & Deciduous & $>50$ & $>50$ & $1+25$ & $20(15)$ \\
\hline \multirow[t]{2}{*}{ Mixed multi-layered (MIX) } & Hazel grouse & Norway spruce & $>60$ & $>40$ & $15+10$ & $1(20)$ \\
\hline & & Deciduous & $>20$ & $>40$ & & \\
\hline
\end{tabular}

\subsubsection{Old spruce forest (SPRUCE)}

The three-toed woodpecker (Picoides tridactylus) is a mediumsized woodpecker, which prefers old-growth coniferous forests with dead spruce trees. It feeds on bark beetle larvae (Scolytidae), which inhabit coniferous trees and other insects found in dead and decaying wood (Murphy and Lehnhausen, 1998). It requires large diameter trees (at least $30-40 \mathrm{~cm}$ ) for nesting which can be found in multi-layered old-growth spruce forests with gap-phase dynamic (Pechacek and d'Oleire-Oltmanns, 2004). The three-toed woodpecker is also found commonly where disturbances such as fire have caused local outbreaks of insects (Winkler et al., 2010). The three-toed woodpecker is associated with a high species richness of other forest birds (Mikusiński et al., 2001).

\subsubsection{Deciduous forest successions (DEC)}

The white-backed woodpecker (Dendrocopos leucotos) prefers late stages of the deciduous phase in the succession after standreplacing forest disturbances, and permanent deciduous corridors along water bodies (Angelstam and Mikusiński, 1994). Habitat requirements include large tracts of deciduous forest (50-90 years old) with high amounts of standing and laying dead wood (Stighäll et al., 2011), and a critical threshold minimum of $15 \%$ suitable habitat in a $20 \mathrm{~km}^{2}$ area (Carlson, 2000). Conserving this species yields a coarse filter for the conservation of several other deciduous forest species (Roberge et al., 2008).

\subsubsection{Mixed multi-layered forest (MIX)}

The hazel grouse (Bonasa bonasia) prefers multi-layered dense rich mixed forests ( $>20$ years) containing deciduous trees for food and coniferous trees (mainly Norway spruce) for shelter (Swenson and Angelstam, 1993). This species avoids open areas and is particularly vulnerable to fragmentation of the forest cover (Åberg et al., 1995). Hazel grouse requires suitable forest stands and a critical threshold minimum of $20 \%$ suitable habitat in a $1 \mathrm{~km}^{2}$ area (Jansson et al., 2004). Forest stand age alone has minimal impact on the species, however, at a landscape scale loss and isolation of habitat may dramatically reduce the occurrence of hazel grouse (Jansson et al., 2004). The hazel grouse is considered as a focal species since it is sedentary and sensitive to habitat isolation (Åberg et al., 2003).

\section{Results}

\subsection{Age class and tree species composition}

The forest age class distributions by area demonstrated a steep gradient among the five study regions (Fig. 3). SE-Bergslagen with final felling ages of 50-65 years was dominated by younger forests. In contrast, LV-Zemgale, BY-Vitebsk and RU-Pskov study region had higher final felling ages, and therefore a relatively even distribution of age classes up to 100 years, but very small proportion of older forest. In contrast, RU-Komi where the timber frontier had just passed had a bimodal age distribution peaking at 30 and 170 years, respectively.

In SE-Bergslagen, there were no deciduous forest stands (Fig. 3). In contrast, there was a large amount of deciduous forest stands in 
SE-Bergslagen LV-Zemgale BY-Vitebsk

RU-Pskov

RU-Komi
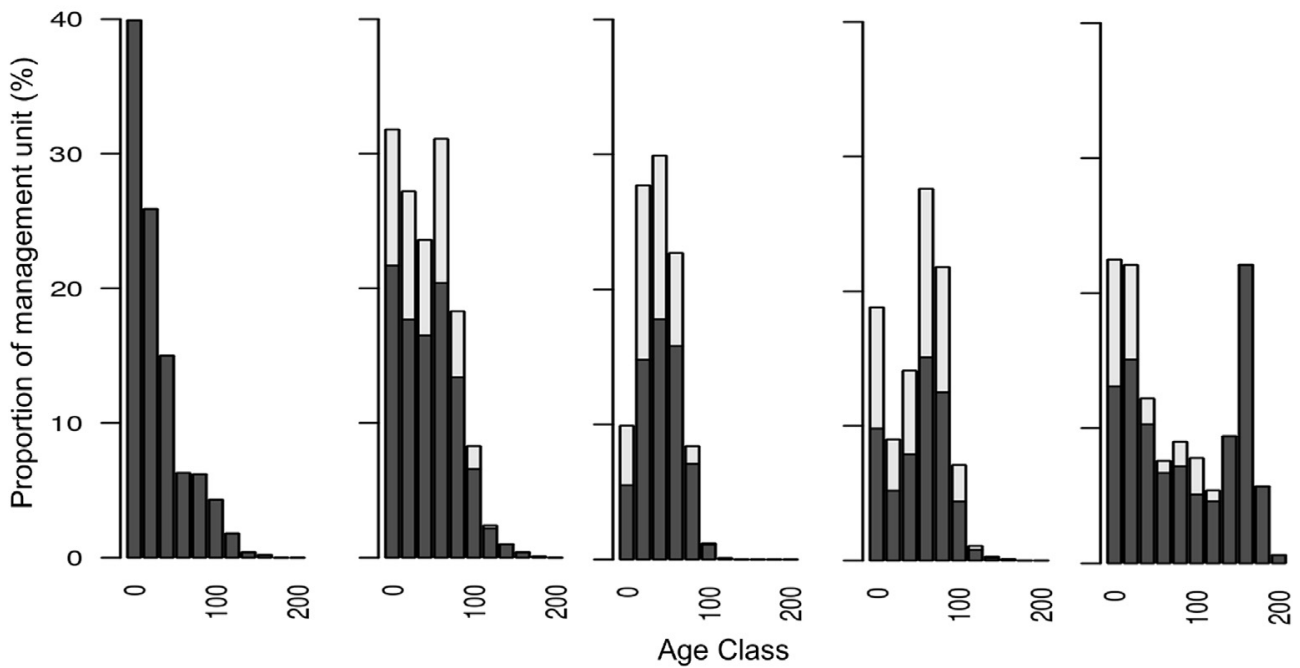

Fig. 3. Age class distributions and the relative area proportion of coniferous stands (dark grey) and stands with $>30 \%$ deciduous trees (light grey) in the five regions studied.

LV-Zemgale, BY-Vitebsk and RU-Pskov, which comprised on average $38-81 \%$ in stands $<100$ years old, but only $1-3 \%$ in forests $>100$ years old (Fig. 3). Finally, RU-Komi was characterized by a high proportion (18\%) of young deciduous forest stands (0-39 years of age), but there were no old deciduous forest stands ( $>140$ years).

\subsection{Wood production indicators}

Regarding wood production indicators (Table 4, Fig. 4), CONWOOD was similar in SE-Bergslagen (9.6\%) and LV-Zemgale (6.8\%), whereas the value was lowest in RU-Pskov (2.7\%) and in RU-Komi (1.0\%). The highest value for this indicator was in BY-Vitebsk (14\%). The introduction of road density as a proxy of accessible wood (ACC_CON) showed the highest value for BY-Vitebsk (11\%) and SEBergslagen (8.8\%), followed by LV-Zemgale (4.2\%), RU-Pskov (1.7\%) and RU-Komi (0.1\%). BIOMASS demonstrated a different pattern bringing BY-Belarus and LV-Zemgale to the top with $77 \%$ and $72 \%$, respectively, followed by SE-Bergslagen (47\%) and RU-Pskov (46\%) and ending with RU-Komi (56\%). Adding the role of accessibility of these stands (ACC_BIO) made SE-Bergslagen (43\%), LV-Zemgale (41\%) and RU-Pskov (32\%) similar, and with the lowest value for RU-Komi (5.9\%). The highest value of the ACC_BIO indicator was observed in BY-Vitebsk (61\%). Statistical analyses show that the 5 study regions were significantly different for CONWOOD $(F=7.9$; $\left.\mathrm{p}<2.2 \mathrm{e}^{-16}\right)$, ACC_CON $\left(\mathrm{F}=61.7 ; \mathrm{p}<2.2 \mathrm{e}^{-16}\right)$, BIOMASS $(\mathrm{F}=44.3$; $\left.\mathrm{p}=<2.2 \mathrm{e}^{-16}\right)$ and ACC_BIO $\left(\mathrm{F}=136.2 ; \mathrm{p}<2.2 \mathrm{e}^{-16}\right)$.

\subsection{Biodiversity indicators}

Regarding the biodiversity conservation indicators (Table 4, Fig. 5), the results along the landscape history gradient were opposite to the production indicators. The indicator PINE was $0 \%$ for both Sweden and Latvia, but 8.0\% for RU-Komi. BY-Vitebsk and RUPskov took an intermediate position with 2.7 and 3.5\%. For SPRUCE the gradient was very steep; from $0 \%$ in LV-Zemgale and $1.3 \%$ in SEBergslagen to 69\% in RU-Komi. BY-Vitebsk was similar to LV-Latvia $(0.2 \%)$, and RU-Pskov was similar to SE-Bergslagen (1.1\%). The amount of deciduous forest habitats (DEC) increased from SEBergslagen (0\%) via RU-Pskov (6.9\%) and LV-Zemgale (25.1\%) to RU-Komi (39\%) and BY-Vitebsk (52\%). Finally, the MIX indicator ranged from 7.6\% in SE-Bergslagen to 75.8\% in RU-Pskov. BY-Vitebsk and RU-Komi indicator values were similar to RU-Pskov (73and $64 \%$, respectively). Almost half of $\mathrm{LV}$-Zemgale was suitable regarding the MIX indicator (49\%). Statistical analyses show that the 5 study regions were significantly different all for indicators; PINE $(\mathrm{F}=8.8 ; \mathrm{p}=3.0 \mathrm{e}-06)$, SPRUCE $(\mathrm{F}=8.0 ; \mathrm{p}<2.2 \mathrm{e}-16)$, DEC $(\mathrm{F}=31.8 ; \mathrm{p}=2.2 \mathrm{e}-16)$ and $\mathrm{MIX}(\mathrm{F}=64.0 ; \mathrm{p}=2.2 \mathrm{e}-16)$.

\section{Discussion}

4.1. Forest landscape history determines production and conservation states

4.1.1. Wood production

From a maximum sustained yield forestry perspective focusing

Table 4

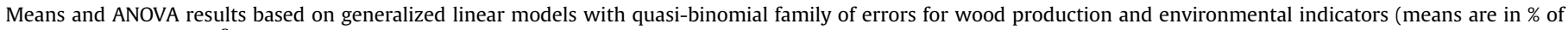
forested land in $100 \mathrm{~km}^{2}$ grid cell); $\mathrm{n}=25$.

\begin{tabular}{|c|c|c|c|c|c|c|c|c|}
\hline Indicator & & $\begin{array}{l}\text { SE-Bergslagen } \\
\text { (mean) }\end{array}$ & $\begin{array}{l}\text { LV-Zemgale } \\
\text { (mean) }\end{array}$ & $\begin{array}{l}\text { BY-Vitebsk } \\
\text { (mean) }\end{array}$ & RU-Pskov (mean) & RU-Komi (mean) & $\begin{array}{l}\text { ANOVA } \\
\text { F-ratio }\end{array}$ & $\begin{array}{l}\text { ANOVA } \\
\text { p-value }\end{array}$ \\
\hline \multirow[t]{4}{*}{ Production } & CONWOOD & 9.6 & 6.8 & 13.7 & 2.7 & 1.0 & 7.9 & $2.2 \mathrm{e}-16$ \\
\hline & BIOMASS & 46.7 & 72.2 & 77.2 & 46.3 & 55.9 & 44.3 & $2.2 \mathrm{e}-16$ \\
\hline & ACC_CON & 8.8 & 4.2 & 11.5 & 1.7 & 0.1 & 61.7 & $2.2 \mathrm{e}-16$ \\
\hline & ACC_BIO & 43.0 & 40.9 & 60.7 & 31.6 & 5.9 & 136.2 & $2.2 \mathrm{e}-16$ \\
\hline \multirow[t]{4}{*}{ Biodiversity conservation } & PINE & 0.0 & 0.0 & 3.5 & 2.7 & 8.0 & 8.8 & $3.0 \mathrm{e}-06$ \\
\hline & SPRUCE & 1.3 & 0.0 & 0.2 & 1.1 & 69.1 & 8.0 & $2.2 \mathrm{e}-16$ \\
\hline & DEC & 0.0 & 25.1 & 51.6 & 6.9 & 39.4 & 31.8 & $2.2 \mathrm{e}-16$ \\
\hline & MIX & 7.6 & 48.5 & 73.3 & 75.8 & 63.6 & 64.0 & $2.2 \mathrm{e}-16$ \\
\hline
\end{tabular}




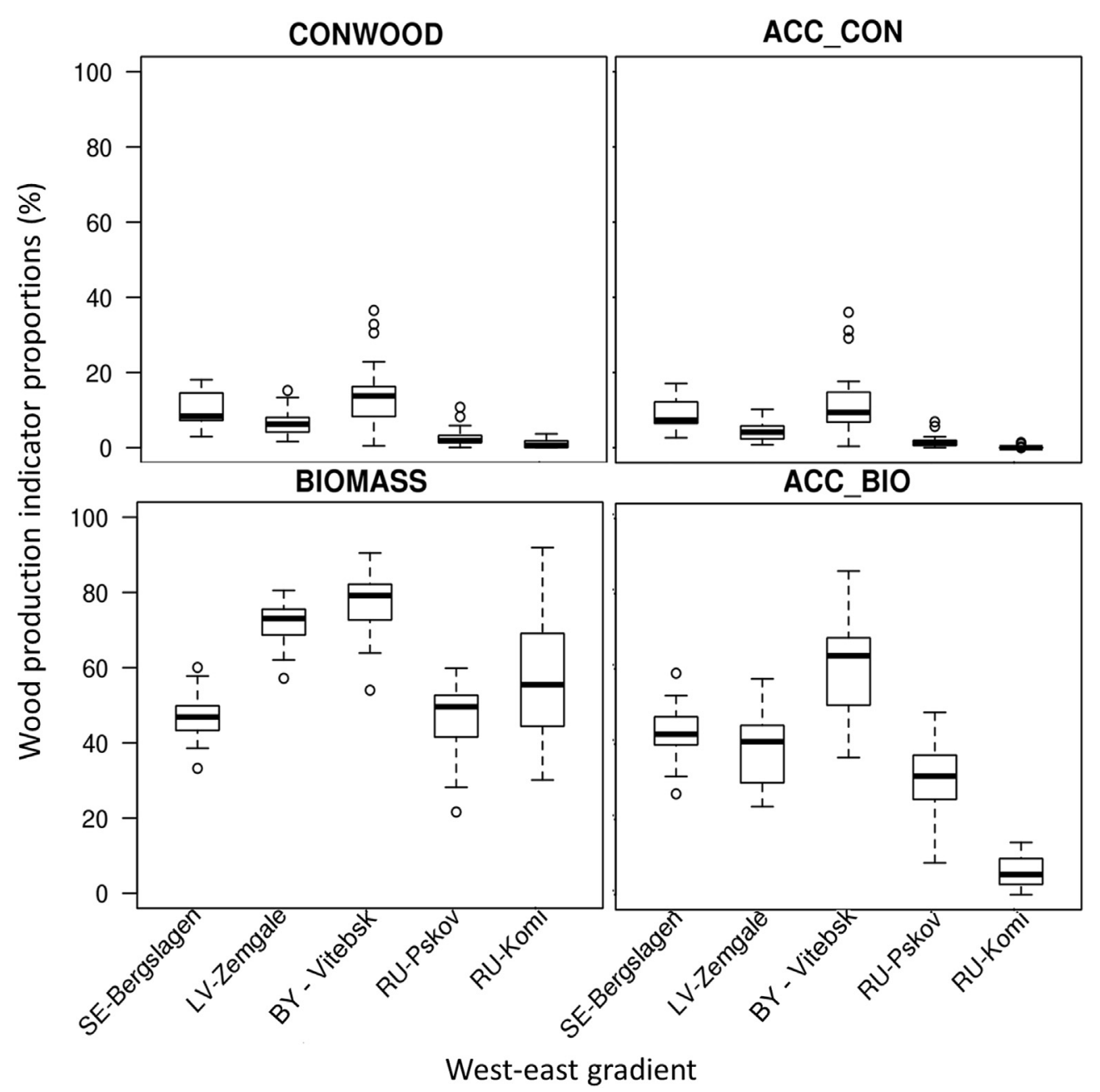

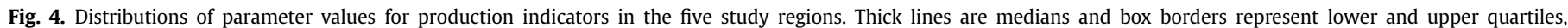
respectively.

on conifers, the forests in SE-Bergslagen, LV-Zemgale and BYVitebsk were more suitable for wood production compared to the two Russian study regions. The reason for this in SE-Bergslagen is the long history of high-input forest management (Elbakidze et al., 2013) with the goal of maximizing the productivity of forest stands measured in terms of charcoal in the past, then sawlogs and pulpwood, and now also biomass. Key features are forest management units with even-aged coniferous stands (Fig. 3), a permanent and dense forest road network that can be used in all seasons allowing access for silviculture, and proximity to consumers and export markets. In Bergslagen, forest stands are young due to low age of final felling (55-65 years), which is linked to high demands on economic profitability of the state forest company Sveaskog by the government. The harvested wood includes small diameter trees used for production of value-added products. In LVZemgale, stand age distribution was close the so-called "normal" age distribution (Puettmann et al., 2009), i.e. with similar proportions in all age classes up to final felling age of 80-100 years. In BY-Vitebsk, the forest stand age distribution was bell-shaped with neither much young nor old forest stands. This is consistent with forest harvesting being made by selective felling. As a result, the proportion of clear-cuts is very low (8\%) in this part of Belarus (Zinovskij, 2006, see also Angelstam et al., 2018). Regarding the CONWOOD and ACC_CON indicators the two Russian study regions had the lowest wood production values. This is a consequence of past wood mining that resulted in vast areas of deciduous forest successions (Naumov et al., 2016, 2017), and a poorly developed road network. The BIOMASS indicator was higher in RU-Komi, BYVitebsk and LV-Zemgale than in SE-Bergslagen and RU-Pskov. However, inclusion of accessibility to harvesting (i.e. ACC_BIO) decreased this indicator's parameter values progressively from West to East (Fig. 4). The gradual decline in road density is associated with the gradually expanding frontier of maximum sustained yield forestry from West towards the East over the past two centuries in northern Europe (e.g. Naumov et al., 2016, 2017).

\subsubsection{Biodiversity conservation}

Biodiversity can be maintained with different levels of ambition (Elbakidze et al., 2011). We focused on four bird species with documented umbrella functions in terms of indicating the presence of a wide range of species adapted to the composition, structure and function of four representative forest habitats that maximum sustained yield forestry does not deliver. Using this approach, the four chosen indicators demonstrated an overall increase in biodiversity among the five case study regions from northern Europe's West to East. This pattern was clearly linked to the different forest landscape histories. In the West, Swedish forestry has gradually been intensified, especially during the latter half of the 20th century (Simonsson, 2016). From a biodiversity conservation perspective, this has caused severe reduction of both mature and 


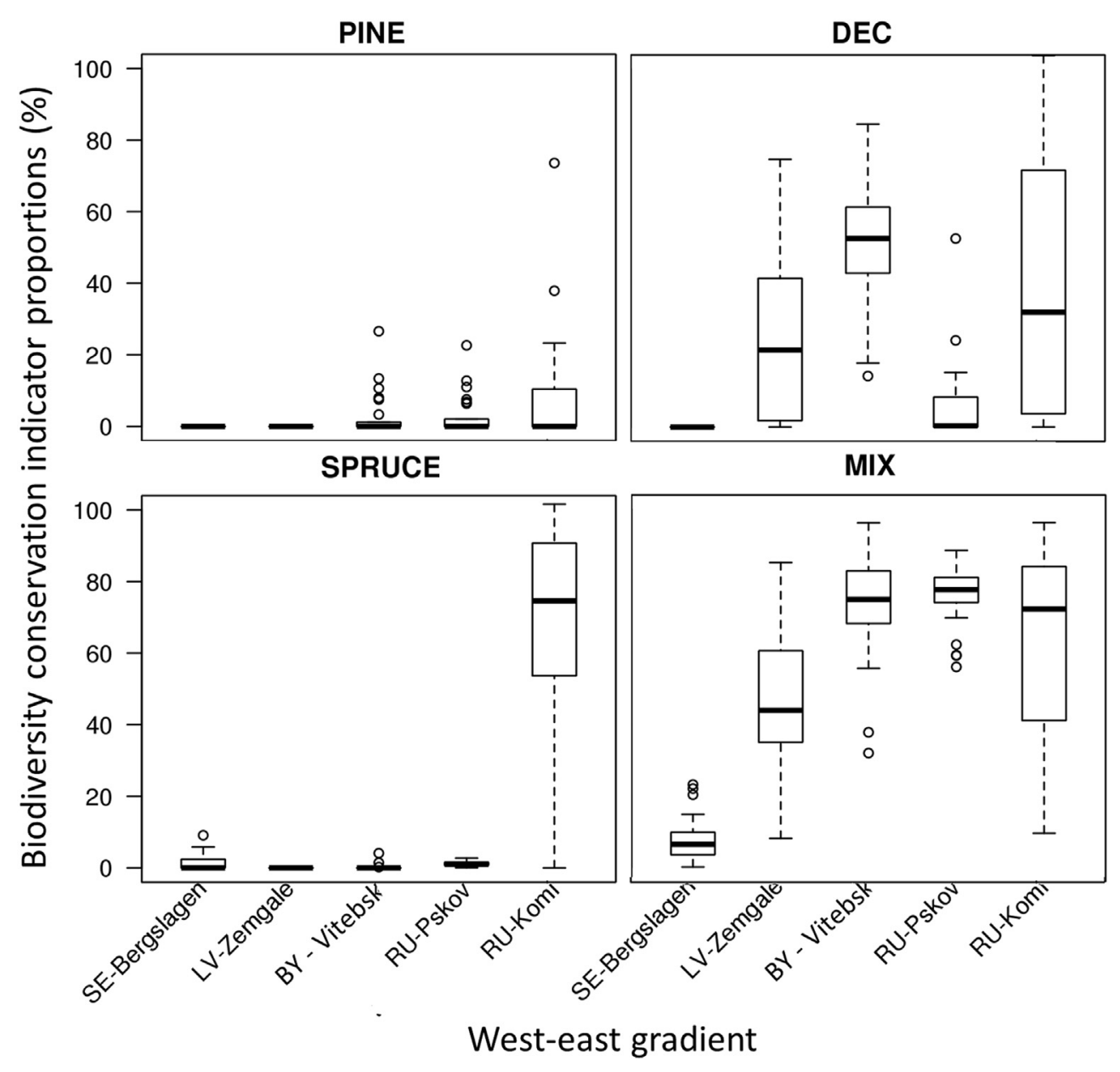

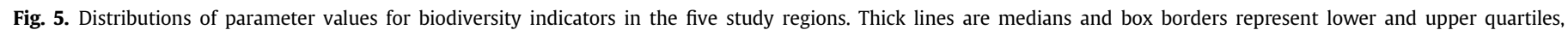
respectively.

old-growth forest (Claesson et al., 2015). The LV-Zemgale region has complex history. The forest cover decreased from $65 \%$ to $42 \%$ from the 17th to the 19th century. By the beginning of the 20th century forest cover had fallen to a minimum of $25 \%$ (Fescenko et al., 2014). Since then, however, the forest cover has continuously increased, reaching $40 \%$ in 2011 . This was due to conversion and abandonment of agricultural areas (Prishchepov et al., 2013, 2017). Overall, this process has been favorable for the maintenance of species in middle-aged deciduous and mixed forests. For example, in the eastern forest-dominated part of LV-Zemgale "wood mining" of old spruce forest first occurred during the World War I. Hence, in the 1970s and 1980s large stands of aspen and birch could be found on sites where spruce would normally dominate in late stages of stand development. The high proportion of deciduous trees is also linked to abandonment of agricultural lands, clear cut areas left for natural regeneration in private forests since mid-1990, and partly also due to nutrient rich soils in this region. The situation in BY-Vitebsk is similar to the adjacent LVZemgale region. In NW Russia, even if intensification is desired (Naumov et al., 2016), this objective has not yet been satisfied (Elbakidze et al., 2013). The composition and structure of forest stands are thus more favorable for biodiversity conservation compared to our study regions with longer histories of maximum sustained yield forestry. In RU-Pskov this development has resulted in even larger amounts of deciduous forest succession than in LVZemgale and BY-Vitebsk. RU-Komi has the shortest forest use history, low-input forest management and a poorly developed road network, which cannot be used during all seasons. As a result, accessible forests are systematically over-harvested (e.g., Nordberg et al., 2013), and left unharvested in remote areas and in riparian protection zones (Naumov et al., 2017). The age distribution in RUKomi was thus bimodal with peaks at 30 and 170 years. This provides for the best opportunities to maintain biodiversity conservation in old pine and spruce forests among the five study regions.

\subsubsection{Wood production and biodiversity conservation compete}

Sustained wood production and biodiversity conservation are two key objectives of sustainable forest management policy. Our analyses clearly show that landscape history matters for the opportunities to satisfy wood production and biodiversity conservation objectives. Indicators for coniferous wood and biomass production and biodiversity conservation, respectively, were clearly inversely related within studied forest management units in Europe' boreal forest (Fig. 6). Intensification of wood and biomass production (Beland Lindahl and Westholm, 2011) including the development of an effective transport infrastructure (Ahtikoski et al., 2008), and biodiversity conservation through functional habitat networks are thus two competing objectives (see also Angelstam et al., 2018; Triviño et al., 2015).

However, as well as the historic frontier of "wood mining" that swept from West to East, i.e. from the center to the periphery of the northern part of the European continent, there is a current frontier of forestry intensification heading in the same direction (Naumov 


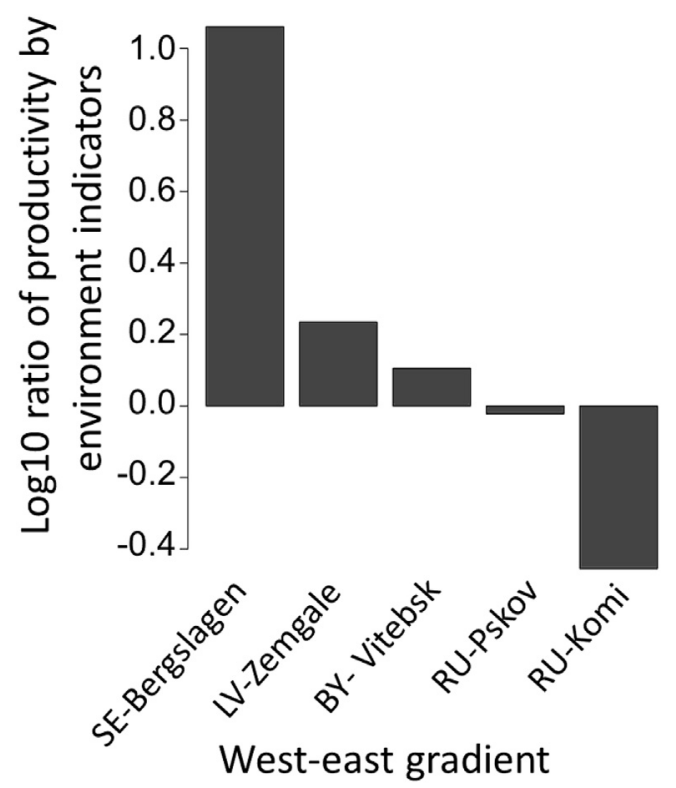

Fig. 6. Ratio of production vs. biodiversity indicators: $\log 10$ (mean (CONWOOD, BIOMASS, ACC_CON, ACC_BIO)/mean (PINE, SPRUCE, DEC, MIX)). Data from Table 4.

et al., 2016, 2017). Since the collapse of the Soviet Union in 1991, Latvia and Belarus have actively progressed towards maximum sustained yield forestry as Sweden did a long time ago. For example, the total volume of final felling since the mid-1990s in Latvia is about $12 \mathrm{M} \mathrm{m} 3$ per year, compared to only 3-4 M m3 during the Soviet period (Latvijas PSR tautas saimnieciba, 1985). Thus, LV-Zemgale's and BY-Vitebsk's future opportunities for maximum sustained yield wood production may become similar to SE-Bergslagen. Nevertheless, provided appropriate spatial planning, their opportunities to maintain functional habitat networks are still much more obtainable and economically favorable than the restoration efforts required in Sweden (Angelstam et al., 2018). In Russia, even if intensification is desired (Naumov et al., 2016) it is not implemented (Elbakidze et al., 2013). Instead wood mining of old-growth remnants is increasing (Naumov et al., 2017).

Three driving forces behind this intensification process are (1) desires to replace fossil fuels with biofuels under the general auspices of encouraging bio-economy growth (EASAC, 2017), (2) restitution of private forest ownership in Latvia and the other Baltic States (Brukas, 2015), and (3) wood being an important source of regional and state income (Rendenieks et al., 2015b). The pressure on the remaining functional habitat networks for biodiversity conservation is thus both increasing over time and expanding to new areas in the boreal forest biome. This is highly relevant for the current debate about land-sharing, which combines wood production with biodiversity conservation across a landscape; and land-sparing, in which more intense forestry is combined with protected areas (Edwards et al., 2014). Clearly, our results stress the need of land-sparing through spatial planning. This applies both to protected areas to assure habitat network functionality (Angelstam et al., 2011b), but also to the development and application of forest management approaches other than clear-felling systems (Elbakidze et al., 2017).

\subsection{Actions towards balancing production and biodiversity conservation}

How can the rivalry between wood production and biodiversity conservation be resolved? Both empirical and modelling studies in northern Europe show that the balance between wood production and biodiversity conservation can only be secured by trading-off one priority for another (Mönkkönen et al., 2014; Triviño et al., 2015; Angelstam et al., 2017b, 2018). Also studies in northeastern USA have highlighted that the maximization of either wood production or biodiversity conservation have negative effects on each other (Nalle et al., 2004; Polasky et al., 2008). A segregated landsparing approach improves the opportunity for delivering broader portfolios of forest ecosystem benefits (Mönkkönen et al., 2014; Triviño et al., 2015; Collas et al., 2017).

One approach is to implement forest zoning by dividing a management unit or region into areas designed and satisfying different objectives (Nitschke and Innes, 2005; Côté et al., 2010; Montigny and MacLean, 2006; Carpentier et al., 2017). Indeed, the zoning approach was employed in the former Soviet Union from 1943 with forests divided into zones for wood production and biodiversity conservation (Naumov et al., 2017). Currently these systems are still maintained in some post-Soviet countries, including Latvia (Ozols, 1995), Belarus and the Russian Federation. In Belarus, according to both the old Forest Code (Anonymous, 2000) and the new one (Anonymous, 2015) there is division of forest into groups and categories. There are production forests and forest for special purposes (conservation, protective and social). The width of water protection zones in Belarus is $50-600 \mathrm{~m}$ (Anonymous, 2014). In Russia, there are zones for production, biodiversity conservation and unmanaged for future harvesting (Anonymous, 2006). The zoning approach in Russia has been primarily used to protect riparian ecosystem and ranges from 50 to $200 \mathrm{~m}$ in width (Naumov et al., 2017). However, progression of forest policy towards forest intensification has already resulted in increased harvesting of old remnant forests previously protected in riparian buffer zones (Naumov et al., 2017).

The zoning approach requires an integrated spatial planning process that can accommodate conflicting management aims, such as intensified wood production and biodiversity conservation. For example, within the zone for wood production, the Swedish intensive forest management model can support an even flow of timber to the industry through tactical and operational forest management planning within a long sustainability horizon (Elbakidze et al., 2013). Latvia is currently embarking on this trajectory. On the other hand, the current approach to forest management in the Russian Federation is mainly based on natural regeneration with minimum investments in silviculture (Angelstam et al., 2017a,b). Therefore, the main concern in the forest sector is about insufficient forest management intensity, which does not meet the expectations of sustaining economic outcomes for the forest industry (Naumov et al., 2016, 2017).

Within the zone for biodiversity conservation, modelling that combines spatially and thematically sufficiently detailed land cover data, and evidence-based knowledge about what focal species require, is a good evidence-based tool to supply spatial planning processes with relevant information for the maintenance of functional green infrastructure within forest management units and at the regional level (Scott et al., 2002; Manton et al., 2005). For European boreal forests we argue that the focal species approach is appropriate for spatial planners to identify priority conservation areas in forest management units. Given empirically well-defined requirements of species, habitat can be quantified using a limited number of tree species and age classes. Additionally, the focal species have been shown to have an umbrella function (Roberge and Angelstam, 2006).

A critical issue is what proportion of a forest management unit should be devoted to wood production and biodiversity conservation, respectively. The Aichi targets (Convention on Biological 
Diversity, 2010) provide guidance consistent with evidence-based knowledge about what is required to maintain biodiversity as a minimum (Svancara et al., 2005). The Aichi target 11 prescribes that $17 \%$ of the land base should be conserved through effectively and equitably managed, ecologically representative and well connected systems of protected areas, and other effective area-based conservation measures. Even if biodiversity conservation targets based on evidence-based knowledge are higher than politically negotiated targets (Svancara et al., 2005), the notion of critical thresholds for local extinction of focal species per se is critical (Hanski, 2011). Additionally, the Aichi target number 7 states that "By 2020 areas under agriculture, aquaculture and forestry are managed sustainably, ensuring conservation of biodiversity". Thus, for operational forest management it is necessary to employ a wider range of forest management systems than the clear-felling system that dominates in northern Europe (Andersson et al., 2016; Elbakidze et al., 2017). For example, Mönkkönen et al. (2014) and Tikkanen et al. (2012) suggested diversification of forest management regimes by refraining from thinning on a proportion of commercial stands as a method to achieve a sufficient balance between wood production and biodiversity conservation by landscape restoration.

However, the opportunity to implement and maintain a zoning approach through spatial planning including both different forest management systems and protected areas (e.g. Gustafsson et al., 2012) among regional forest governance and ownership contexts varies. The four countries and five regions involved in this study illustrate this. Societal steering in Russia and Belarus is top-down and forests are state-owned. This is in stark contrast to countries with many forest owners and small fragmented forest land ownership, such as in Sweden and Latvia. Thus, different ways and incentives to satisfy production and conservation objectives need to be used in different regions. Place-based collaborative learning among stakeholders about the states and trends of different dimensions of sustainable forest management can be effective tools (Nordberg et al., 2013). For instance, Model Forests and other landscape approach concepts can play important roles to test, apply and scale up innovative ideas and disseminate knowledge about how to implement sustainable forest management policy (Elbakidze et al., 2010; Axelsson et al., 2011). This requires in-depth understanding of stakeholders' perceptions, ability and willingness to act at different levels of governance (e.g., Blicharska et al., 2011).

\section{Conclusion}

Wood production and biodiversity conservation are two competing objectives of sustainable forest management. Our comparison of five regions in the forest landscape history gradient in northern Europe's' West and East shows that when indicators for wood production perform well, the opportunities for biodiversity are poor. The Swedish case study region performed well regarding wood production but did not deliver representative functional green infrastructures for biodiversity conservation. Latvia occupied an intermediate position regarding wood production and biodiversity conservation. In contrast, the habitat networks were functional in the Belarusian and Russian case studies, which had the shortest forest use histories. This demonstrates difficulties in terms of achieving competing policy objectives within individual forest management units, unless zoning of different functions is satisfied. Five key recommendations are (1) to restore biodiversity in regions with a long forest use history (e.g. Sweden), (2) to develop alternatives to clear-felling systems for intensified wood production that are ecologically sustainable in regions with a short forest use history (e.g. Russia), (3) adapt spatial planning approaches of both protected areas and different forest management systems to regional governance and tenure contexts, and (4) to communicate evidence-based knowledge about how much habitat focal species require, and (5) for spatial and forest planners in different contexts to share their knowledge and experience. Exchanging experiences among regions with different landscape histories can bridge knowledge gaps through collaborative learning.

\section{Acknowledgements}

This work was supported by funding from the Swedish Research Council FORMAS [grant number 2011-1737] to Per Angelstam and from the Swedish Institute [grant number 10976/2013] to Marine Elbakidze.

\section{References}

Åberg, J., Jansson, G., Swenson, J.E., Angelstam, P., 1995. The effect of matrix on the occurrence of hazel grouse (Bonasa bonasia) in isolated habitat fragments. Oecologia 103, 265-269.

Åberg, J., Swenson, J.E., Angelstam, P., 2003. The habitat requirements of hazel grouse (Bonasa bonasia) in managed boreal forest and applicability of forest stand descriptions as a tool to identify suitable patches. For. Ecol. Manag. 175, 437-444.

Ahtikoski, A., Heikkilä, J., Alenius, V., Siren, M., 2008. Economic viability of utilizing biomass energy from young stands-the case of Finland. Biomass Bioenergy 32, 988-996.

Aksenov, D., Dobrynin, D., Dubinin, M., Egorov, A., Isaev, A., Karpachevskiy, M., Laestadius, L., Potapov, P., Purekhovskiy, A., Turubanova, S., Yaroshenko, A. 2002. Atlas of Russia's Intact forest Landscapes. Global Forest Watch Russia., Moscow.

Andersson, G., Berg, M., Bergkvist, U., Ewelönn, K., Forslund, M., Hansson, S., Hjärtfors, E., Ligne, D., Möller, L., Nyman, O., Petre, E., Perers, K., SalanderBjörklund, E., Tengblad, L.-L., Westman, P., 2016. Tillväxt, mångbruk och värdeskapande av skogen som resurs: underlagsrapport frăn arbetsgrupp 1 inom nationellt skogsprogram. Stockholm. (In Swedish).

Angelstam, P., 2004. Habitat thresholds and effects of forest landscape change on the distribution and abundance of Black Grouse and Capercaillie. Ecol. Bull. 51, $173-187$.

Angelstam, P., Andersson, K., Axelsson, R., Degerman, E., Elbakidze, M., Sjölander, P., Törnblom, J., 2015. Barriers and bridges for sustainable forest management: the role of landscape history in Swedish Bergslagen. In: Kirby, K.J., Watkins, D. (Eds.), Europe's Changing Woods and Forests: from Wildwood to Cultural Landscapes. CABI, pp. 290-305.

Angelstam, P., Andersson, K., Axelsson, R., Elbakidze, M., Jonsson, B.G., Roberge, J.M., 2011b. Protecting forest areas for biodiversity in Sweden 1991-2010: policy implementation process and outcomes on the ground. Silva Fenn. 45, $1111-1133$.

Angelstam, P., Andersson, K., Isacson, M., Gavrilov, D.V., Axelsson, R., Backstrom, M., Degerman, E., Elbakidze, M., Kazakova-Apkarimova, E.Y., Sartz, L., Sädbom, S., Tornblom, J., 2013a. Learning about the history of landscape use for the future: consequences for ecological and social systems in Swedish Bergslagen. Ambio 42 (2), 146-159.

Angelstam, P., Axelsson, R., Elbakidze, M., Laestadius, L., Lazdinis, M., Nordberg, M. Pătru-Stupariu, I., Smith, M., 2011a. Knowledge production and learning for sustainable forest management on the ground: Pan-European landscapes as a time machine. Forestry 84, 581-596.

Angelstam, P., Elbakidze, M., Axelsson, R., Koch, N.E., Tyupenko, T.I., Mariev, A.N., Myhrman, L., 2013b. Knowledge production and learning for sustainable landscapes: forewords by the researchers and stakeholders. Ambio 42 (2), $111-115$.

Angelstam, P., Majewski, P., Bondrup-Nielsen, S., 1995. West-east cooperation in Europe for sustainable boreal forests. Water, Air, Soil Pollut. 82, 3-11.

Angelstam, P., Manton, M., Pedersen, S., Elbakidze, M., 2017b. Disrupted trophic interactions affect recruitment of boreal deciduous and coniferous trees in northern Europe. Ecol. Appl. 27, 1108-1123.

Angelstam, P., Mikusiński, G., 1994. Woodpecker assemblages in natural and managed boreal and hemiboreal forest: a review. Ann. Zool. Fenn. 31, 157-172.

Angelstam, P., Naumov, V., Elbakidze, M., 2017a. Transitioning from Soviet wood mining to sustainable forest management by intensification: are tree growth rates different in northwest Russia and Sweden? For. Int. J. For. Res. 90, 292-303.

Angelstam, P., Naumov, V., Elbakidze, M., Manton, M., Priednieks, J., Rendenieks, Z., 2018. Wood production and biodiversity conservation are rival forestry objectives in Europe's Baltic Sea Region. Ecosphere 9 e02119-n/a.

Angelstam, P., Roberge, J.M., Lõhmus, A., Bergmanis, M., Brazaitis, G., DönzBreuss, M., Edenius, L., Kosinski, Z., Kurlavicius, P., Lārmanis, V., Lūkins, M., Mikusiński, G., Račinskis, E., Strazds, M., Tryjanowski, P., 2004. Habitat modelling as a tool for landscape-scale conservation: a review of parameters for focal forest birds. Ecol. Bull. 51, 427-453. 
Angelstam, P.K., Bütler, R., Lazdinis, M., Mikusiński, G., Roberge, J.-M., 2003. Habitat thresholds for focal species at multiple scales and forest biodiversity conservation; dead wood as an example. Ann. Zool. Fenn. 40, 473-482.

Angelstam, P., Kuuluvainen, T., 2004. Boreal forest disturbance regimes, successional dynamics and landscape structures - a European perspective. Ecol. Bull. 51, 117-136.

Anonymous, 2000. Lesnoy Kodeks Respubliki Belarus' (Forest Code of the Republic Belarus). June 14, 2000. No 420-3. (In Russian).

Anonymous, 2006. Lesnoy Kodeks Rossiyskoy Federatsii (forest code of the Russian federation). State Duma Russ. Fed. 200 (In Russian).

Anonymous, 2010. Programma razvitiya lesnovo khozyaistva Respubliki Belarus na 2011-2015 gody (Forestry development programme in the Republic of Belarus for 2011-2015). Counc. Minist. Repub. Belarus (In Russian).

Anonymous, 2014. Vodniy Kodeks Respubliki Belarus' (Water Code of the Republic Belarus). April 30, 2014. No 149-3. (In Russian).

Anonymous, 2015. Lesnoy Kodeks Respubliki Belarus' (Forest Code of the Republic Belarus). December 24, 2015. No 332-3. (In Russian).

Axelsson, R., Angelstam, P., Elbakidze, M., Stryamets, N., Johansson, K.-E., 2011. Sustainable development and sustainability: landscape approach as a practical interpretation of principles and implementation concepts. J. Landsc. Ecol. 4 (3), $5-30$.

Balee, W.L., 2002. Advances in Historical Ecology. Columbia University Press, New York.

Beland Lindahl, K., Westholm, E., 2011. Food, paper, wood, or Energy? Global trends and future Swedish forest use. Forests 2, 51.

Blicharska, M., Angelstam, P., Antonson, H., Elbakidze, M., Axelsson, R., 2011. Road, forestry and regional planners' work for biodiversity conservation and public participation: a case study in Poland's hotspots regions. J. Environ. Plan. Manag. 54 (10), 1373-1395.

Bollmann, K., Braunisch, V., 2013. To Integrate or to Segregate: Balancing Commodity Production and Biodiversity Conservation in European Forests, Integrative Approaches as an Opportunity for the Conservation of forest Biodiversity. European Forest Institute, Freiburg, p. 18

Brown, J.H., 1995. Macroecology. University of Chicago Press, Chicago.

Brukas, V., 2015. New World, old ideas - a narrative of the Lithuanian forestry transition. J. Environ. Policy \& Plan. 17, 495-515.

Brumelis, G., Jonsson, B.G., Kouki, J., Kuuluvainen, T., Shorohova, E., 2011. Forest naturalness in northern Europe: perspectives on processes, structures and species diversity. Silva Fenn. 45, 807-821.

Carlson, A., 2000. The effect of habitat loss on a deciduous forest specialist species: the White-backed Woodpecker (Dendrocopos leucotos). For. Ecol. Manag. 131, $215-221$.

Carpentier, S., Filotas, E., Handa, I.T., Messier, C., 2017. Trade-offs between timber production, carbon stocking and habitat quality when managing woodlots for multiple ecosystem services. Environ. Conserv. 44 (1), 14-23.

Claesson, S., Duvemo, K., Lundström, A., Wikberg, P.-E., 2015. Skogliga konsekvensanalyser. Skogsstyrelsen. . Sweden (In Swedeish).

Collas, L., Green, R.E., Ross, A., Wastell, J.H., Balmford, A., 2017. Urban development, land sharing and land sparing: the importance of considering restoration. J. Appl. Ecol. 54 (6), 1865-1873.

Convention on Biological Diversity, 2010. The Strategic Plan for Biodiversity 20112020 and the Aichi Biodiversity Target. UNEP.

Côté, P., Tittler, R., Messier, C., Kneeshaw, D.D., Fall, A., Fortin, M.-J., 2010. Comparing different forest zoning options for landscape-scale management of the boreal forest: possible benefits of the TRIAD. For. Ecol. Manag. 259 (3), 418-427.

Dawson, L., Elbakidze, M., Angelstam, P., Gordon, J., 2017. Governance and management dynamics of landscape restoration at multiple scales: learning from successful environmental managers in Sweden. J. Environ. Manag. 197, 24-40.

Diamond, J., 1986. Overview: laboratory experiments, field experiments, and natural experiments. Community Ecol.

Djupström, L.B., Weslien, J., Hoopen, J.t., Schroeder, L.M., 2012. Restoration of habitats for a threatened saproxylic beetle species in a boreal landscape by retaining dead wood on clear-cuts. Biol. Conserv. 155, 44-49.

Drushka, K., 2003. Canada's Forests: a History. McGill-Queen's University Press, London.

EASAC, 2017. Multi-functionality and Sustainability in the European Union's Forests. European Academies' Science Advisory Council (EASAC) report 32.

Edwards, D.P., Gilroy, J.J., Woodcock, P., Edwards, F.A., Larsen, T.H., Andrews, D.J.R., Derhé, M.A., Docherty, T.D.S., Hsu, W.W., Mitchell, S.L., Ota, T., Williams, L.J. Laurance, W.F., Hamer, K.C., Wilcove, D.S., 2014. Land-sharing versus landsparing logging: reconciling timber extraction with biodiversity conservation. Glob. Change Biol. 20, 183-191.

Elbakidze, M., Andersson, K., Angelstam, P., Armstrong, G.W., Axelsson, R., Doyon, F., Hermansson, M., Jacobsson, J., Pautov, Y., 2013. Sustained yield forestry in Sweden and Russia: how does it correspond to sustainable forest management policy? AMBIO 42, 160-173.

Elbakidze, M., Angelstam, P., Andersson, K., Nordberg, M., Pautov, Y., 2011. How does forest certification contribute to boreal biodiversity conservation? Standards and outcomes in Sweden and NW Russia. For. Ecol. Manag. 262, 1983-1995.

Elbakidze, M., Angelstam, P., Sandström, C., Axelsson, R., 2010. Multi-stakeholder collaboration in Russian and Swedish model forest initiatives: adaptive governance toward sustainable forest management? Ecol. Soc. 15, 14.

Elbakidze, M., Angelstam, P., Yamelynets, T., Dawson, L., Gebrehiwot, M. Stryamets, N., Johansson, K.E., Garrido, P., Naumov, V., Manton, M., 2017. A bottom-up approach to map land covers as potential green infrastructure hubs for human well-being in rural settings: a case study from Sweden. Landsc Urban Plan. 168, 72-83.

Elbakidze, M., Ražauskaitè, R., Manton, M., Angelstam, P., Mozgeris, G., Brūmelis, G. Brazaitis, G., Vogt, P., 2016. The role of forest certification for biodiversity conservation: Lithuania as a case study. Eur J For. Res 1-16.

European Commission, 2013. Green Infrastructure (GI) - Enhancing Europe's Natural Capital. Communication from the Commission to the European Parliament, the council, the European Economic and Social Committee and the Committee of the Regions. European Commission: Environment, Brussels.

European Forest Institute, 2013. Implementing Criteria and Indicators for Sustainable forest Management in Europe. European Forest Institute, Joensuu, Finland.

Fahrig, L., 2003. Effects of habitat fragmentation on biodiversity. Annu. Rev. Ecol Evol. Syst. 34, 487-515.

Fedorenchik, A., 2014. Mekhanizatsiya Lesozagotovok: Kak Eto Bylo ((Mechanization of forest Harvesting - How it Was)). Forest and Hunting management, p. 4 (In Russian).

Fescenko, A., Nikodemus, O., Brūmelis, G., 2014. Past and contemporary changes in forest cover and forest fontinuity in relation to soils (southern Latvia). Pol. J. Ecol. 62, 625-638.

Fox, J., 2015. Applied Regression Analysis and Generalized Linear Models. Sage Publications, London.

Gardner, R.H., Turner, M.G., O'Neill, R.V., Lavorel, S., 1991. Simulation of the scaledependent effects of landscape boundaries on species persistence and dispersal. In: Holland, M.M., Risser, P.G., Naiman, R.J. (Eds.), Ecotones: the Role of Landscape Boundaries in the Management and Restoration of Changing Environments. Springer US, Boston, pp. 76-89.

Gergle, S.E., Turner, M.G., 2001. Learning Landscape Ecology: a Practicle Guide to Concepts and Techniques. Springer-Verlag, New York.

Gibson, L.A., Wilson, B.A., Cahill, D.M., Hill, J., 2004. Modelling habitat suitability of the swamp antechinus (Antechinus minimus maritimus) in the coastal heathlands of southern Victoria, Australia. Biol. Conserv. 117, 143-150.

Goltsev, V., Tolonen, T., Syunev, V., Dahlin, B., Gerasimov, Y., Karvinen, S., 2012 Wood harvesting and Logistics in Russia-focus on Research and Business Opportunities. Working Papers of the Finnish Forest Research Institute, p. 221.

Gusev, A.P., 2014. Land-use history as a factor of the contemporary state of a plant cover: an example from Southeastern Belarus. Contemp. Problems Ecol. 7, $182-186$.

Gustafsson, L., Baker, S.C., Bauhus, J., Beese, W.J., Brodie, A., Kouki, J. Lindenmayer, D.B., Lõhmus, A., Pastur, G.M., Messier, C., Neyland, M., Palik, B., Sverdrup-Thygeson, A., Volney, W.J.A., Wayne, A., Franklin, J.F., 2012. Retention forestry to maintain multifunctional forests: a World perspective. BioScience 62, 633-645.

Halme, P., Allen, K.A., Auniņš, A., Bradshaw, R.H.W., Brūmelis, G., Čada, V., Clear, J.L., Eriksson, A.-M., Hannon, G., Hyvärinen, E., Ikauniece, S., Iršènaitè, R. Jonsson, B.G., Junninen, K., Kareksela, S., Komonen, A., Kotiaho, J.S., Kouki, J. Kuuluvainen, T., Mazziotta, A., Mönkkönen, M., Nyholm, K., Oldén, A. Shorohova, E., Strange, N., Toivanen, T., Vanha-Majamaa, I., Wallenius, T., Ylisirniö, A.-L., Zin, E., 2013. Challenges of ecological restoration: lessons from forests in northern Europe. Biol. Conserv. 167, 248-256.

Hanski, I., 2011. Habitat loss, the dynamics of biodiversity, and a perspective on conservation. AMBIO A J. Hum. Environ. 40, 248-255.

Hess, G.R., King, T.J., 2002. Planning open spaces for wildlife: I. Selecting focal species using a Delphi survey approach. Landsc. Urban Plan. 58, 25-40.

Hinde, J., Demétrio, C.G.B., 1998. Overdispersion: models and estimation. Comput. Statistics Data Analysis 27, 151-170.

Hjeljord, O., Wegge, P., Rolstad, J., Ivanova, M., Beshkarev, A.B., 2000. Spring-summer movements of male capercaillie Tetrao urogallus: a test of the 'landscape mosaic' hypothesis. Wildl. Biol 6, 251-256.

Holopainen, P., Ollonqvist, P., Viitanen, J., 2006. Factors Affecting Investments in Northwest Russian forest Sector and Industry. Working Papers of the Finnish Forest Research Institute, p. 32.

Jansson, G., Angelstam, P., Åberg, J., Jon, E.S., 2004. Management targets for the conservation of Hazel Grouse in boreal landscapes. Ecol. Bull. 51, 259-264.

Jonsson, B.G., Ekström, M., Esseen, P.A., Grafström, A., Ståhl, G., Westerlund, B., 2016 Dead wood availability in managed Swedish forests - policy outcomes and implications for biodiversity. For. Ecol. Manag. 376, 174-182.

Josephson, P., Dronin, N., Mnatsakanian, R., Cherp, A., Efremenko, D., Larin, V., 2013. An Environmental History of Russia. Cambridge University Press, Cambridge.

Kliskey, A.D., Lofroth, E.C., Thompson, W.A., Brown, S., Schreier, H., 1999. Simulating and evaluating alternative resource-use strategies using GIS-based habitat suitability indices. Landsc. Urban Plan. 45, 163-175.

Kurlavicius, P., Kuuba, R., Lukins, M., Mozgeris, G., Tolvanen, P., Angelstam, P. Karjalainen, H., Walsh, M., 2004. Identifying high conservation value forests in the Baltic States from forest databases. Ecol. Bull. 51, 351-366.

Kuuluvainen, T., 2002. Natural variability of forests as a reference for restoring and managing biological diversity in boreal Fennoscandia. Silva Fenn. 36, 97-125.

Lambeck, R.J., 1997. Focal species: a multi-species umbrella for nature conservation. Conserv. Biol. 11, 849-856.

Latvijas PSR tautas saimnieciba, 1985. Statistical Yearbook for 1984 (People's Economy of Latvian SSR), p. 83 (In Latvian).

Lindenmayer, D., Franklin, J.F., 2002. Conserving forest Biodiversity: a Comprehensive Multiscaled Approach. Island Press.

Manton, M., Angelstam, P., Mikusiński, G., 2005. Modelling habitat suitability for deciduous forest focal species - a sensitivity analysis using different satellite land cover data. Landsc. Ecol 20, 827-839. 
Margules, C.R., Pressey, R.L., 2000. Systematic conservation planning. Nature 405, 243.

Mikusiński, G., Gromadzki, M., Chylarecki, P., 2001. Woodpeckers as indicators of forest bird diversity. Conserv. Biol. 15, 208-217.

Miller, J.R., Hobbs, R.J., 2007. Habitat Restoration-do we know what we're doing? Restor. Ecol. 15, 382-390.

Montigny, M.K., MacLean, D.A., 2006. Triad forest management: scenario analysis of forest zoning effects on timber and non-timber values in New Brunswick, Canada. Chron 82 (4), 496-511.

Moiseev, N.A., 2001. Lesnoye Khozyaistvo Rossii za 100 Lyet. Rossiya V Okhruzhayuschem Mire (Forest Management in Russia after 100 Years. Russia in the Surrounding World), pp. 80-99 (In Russian).

Mönkkönen, M., Juutinen, A., Mazziotta, A., Miettinen, K., Podkopaev, D. Reunanen, P., Salminen, H., Tikkanen, O.-P., 2014. Spatially dynamic forest management to sustain biodiversity and economic returns. J. Environ. Manag. 134, 80-89.

Murphy, E.C., Lehnhausen, W.A., 1998. Density and foraging ecology of woodpeckers following a stand-Replacement fire. J. Wildl. Manag. 62, 1359-1372.

Nalle, D.J., Montgomery, C.A., Arthur, J.L., Polasky, S., Schumaker, N.H., 2004. Modeling joint production of wildlife and timber. J. Environ. Econ. Manag. 48, 997-1017.

Naumov, V., Angelstam, P., Elbakidze, M., 2016. Barriers and bridges for intensified wood production in Russia: insights from the environmental history of a regional logging frontier. For. Policy Econ. 66, 1-10.

Naumov, V., Angelstam, P., Elbakidze, M., 2017. Satisfying rival forestry objectives in the Komi Republic: effects of Russian zoning policy change on wood production and riparian forest conservation. Can. J. For. Res. 47, 1339-1349.

Nelson, H., 1913. En Bergslagsbygd [a settled area in Bergslagen]. Ymer 33, 278-352 (in Swedish).

Newey, S., Mustin, K., Bryce, R., Fielding, D., Redpath, S., Bunnefeld, N., Daniel, B., Irvine, R.J., 2016. Impact of management on avian communities in the Scottish Highlands. PLoS ONE 11, e0155473.

Nitschke, C.R., Innes, J.L., 2005. The application of forest zoning as an alternative to multiple-use forestry. IUFRO Res. Ser. 11, 97-124.

Nordberg, M., Angelstam, P., Elbakidze, M., Axelsson, R., 2013. From logging frontier towards sustainable forest management: experiences from boreal regions of North-West Russia and North Sweden. Scand. J. For. Res. 28, 797-810.

Nordfjell, T., Athanassiadis, D., Talbot, B., 2003. Fuel consumption in forwarders. Int. J. For. Eng. 14, 11-20.

Östlund, L., Zackrisson, O., Axelsson, A.L., 1997. The history and transformation of a Scandinavian boreal forest landscape since the 19th century. Can. J. For. Res. 27, 1198-1206.

Ozols, A., 1995. The forest and forestry in Latvia. Balt. For. 1, 17-21.

Pakkala, T., Pellikka, J., Lindén, H., 2003. Capercaillie Tetrao urogallus - a good candidate for an umbrella species in taiga forests. Wildl. Biol. 9, 309-316.

Parikka, M., 2004. Global biomass fuel resources. Biomass Bioenergy 27, 613-620.

Pechacek, P., d'Oleire-Oltmanns, W., 2004. Habitat use of the three-toed woodpecker in central Europe during the breeding period. Biol. Conserv. 116, $333-341$.

Pennanen, J., 2002. Forest age distribution under mixed-severity fire regimes-a simulation-based analysis for middle boreal Fennoscandia. Silva Fenn. 36, 213-231.

Polasky, S., Nelson, E., Camm, J., Csuti, B., Fackler, P., Lonsdorf, E., Montgomery, C., White, D., Arthur, J., Garber-Yonts, B., Haight, R., Kagan, J., Starfield, A. Tobalske, C., 2008. Where to put things? Spatial land management to sustain biodiversity and economic returns. Biol. Conserv. 141, 1505-1524.

Prishchepov, A.V., Müller, D., Baumann, M., Kuemmerle, T., Alcantara, C. Radeloff, V.C., 2017. Underlying drivers and spatial determinants of post-soviet agricultural land abandonment in temperate eastern Europe. In: Gutman, G. Radeloff, V. (Eds.), Land-cover and Land-use Changes in Eastern Europe after the Collapse of the Soviet Union in 1991. Springer International Publishing, Cham, pp. 91-117.

Prishchepov, A.V., Müller, D., Dubinin, M., Baumann, M., Radeloff, V.C., 2013. Determinants of agricultural land abandonment in post-Soviet European Russia. Land Use Policy 30, 873-884.

Puettmann, K.J., Coates, K.D., Messier, C., 2009. A Critique of Silviculture: Managing for Complexity (Island, Washington).

Pülzl, H., Kleinschmit, D., Arts, B., 2014. Bioeconomy - an emerging meta-discourse affecting forest discourses? Scand. J. For: Res. 29, 386-393.

Ranius, T., Roberge, J.-M., 2011. Effects of intensified forestry on the landscape-scale extinction risk of dead wood dependent species. Biodivers Conserv 20, 2867-2882.

Red'ko, G.I., Babych, N.A., 1993. Korabelny les vo slavu flota rossiyskovo (Ships' forest for the glory of Russian fleet). North-Western Publishing House Arkhangelsk (In Russian).

Rendenieks, Z., Nikodemus, O., Brūmelis, G., 2015a. Dynamics in forest pattern during times of forest policy changes in Latvia. Eur J For. Res 134, 819-832.

Rendenieks, Z., Nikodemus, O., Brūmelis, G., 2015b. The implications of stand composition, age and spatial patterns of forest regions with different ownership type for management optimisation in northern Latvia. For. Ecol. Manag. 335,
$216-224$.

Roberge, J.-M., Angelstam, P., 2004. Usefulness of the umbrella species concept as a conservation tool. Conserv. Biol. 18, 76-85.

Roberge, J.-M., Angelstam, P., 2006. Indicator species among resident forest birds a cross-regional evaluation in northern Europe. Biol. Conserv. 130, 134-147.

Roberge, J.-M., Mikusiński, G., Svensson, S., 2008. The white-backed woodpecker: umbrella species for forest conservation planning? Biodivers Conserv 17, $2479-2494$.

Scott, J.M., Heglund, P.J., Morrison, M.L., Haufler, J.B., Raphael, M.G., Wall, W.A., Samson, F.B., 2002. Predicting Species Occurrences: Issues of Scale and Accuracy. Island Press, London.

Sherstyokova, T.A., 2012. Lesnoye Khozyaistvo Respubliki Komi (Forest Management in the Republic of Komi). Komistat, Syktyvar (In Russian).

Similiä, M., Junninen, K., 2012. Ecological Restoration and Management in Boreal Forests: Best Practices from Finland. Metsähallitus Natural Heritage Services, Vantaa, Finland.

Simonsson, P., 2016. Conservation Measures in Swedish Forests. Department of Forest Ecology and Management. Swedish University of Agricultural Sciences, Umeå.

Skogsstyrelsen, 2013. Skogsstatistisk Årsbok 2013. Mölnlycke: Skogsstyrelsen ((Swedish statistical yearbook of forestry)). Stockholm, Sweden. (In Swedish).

Stanturf, J.A., 2015. Restoration of Boreal and Temperate Forests. CRC Press, London.

Stephens, M.B.M., Ripa, I., Lundström, L., Persson, T., Bergman, M., Ahl, C.-H., Wahlgren, P.-O., Persson, Wickström, L., 2009. Synthesis of the bedrock geology in the region, Fennoscandian Shield, south-central Sweden. Rep. Ba 58, 259 (Geol. Surv. of Swed., Uppsala, Sweden).

Stighäll, K., Roberge, J.-M., Andersson, K., Angelstam, P., 2011. Usefulness of biophysical proxy data for modelling habitat of an endangered forest species: the white-backed woodpecker Dendrocopos leucotos. Scand. J. For. Res. 26, $576-585$.

Storch, I., 1997. Male territoriality, female range use, and spatial organisation of Capercaillie Tetrao urogallus leks. Wildl. Biol. 3, 149-161.

Susko, U., 1997. Natural Forests of Riga - a Study on Biodiversity Structures, Dependent Species and forest History. WWF, Riga.

Suter, W., Graf, R.F., Hess, R., 2002. Capercaillie (Tetrao urogallus) and avian biodiversity: testing the umbrella-species concept. Conserv. Biol. 16, 778-788.

Svancara, L.K., Brannon, J.R., Scott, M., Groves, C.R., Noss, R.F., Pressey, R.L., 2005. Policy-driven versus evidence-based conservation: a review of political targets and biological needs. BioScience 55, 989-995.

Sverdrup, H., Stjernquist, I., 2013. Developing Principles and Models for Sustainable Forestry in Sweden. Springer Science and Business Media, Dordrecht.

Swenson, J.E., Angelstam, P., 1993. Habitat separation by sympatric forest grouse in Fennoscandia in relation to boreal forest succession. Can. J. Zoology 71, 1303-1310.

Tērauds, A., Brūmelis, G., Nikodemus, O., 2011. Seventy-year changes in tree species composition and tree ages in state-owned forests in Latvia. Scand. J. For. Res. 26, 446-456.

The Montreal process, 2015. Criteria and Indicators for the Conservation and Sustainable Management of Temperate and Boreal Forests, 5th (Hull: The Montreal process).

Tikkanen, O.-P., Matero, J., Mönkkönen, M., Juutinen, A., Kouki, J., 2012. To thin or not to thin: bio-economic analysis of two alternative practices to increase amount of coarse woody debris in managed forests. Eur J For. Res 131, $1411-1422$.

Triviño, M., Juutinen, A., Mazziotta, A., Miettinen, K., Podkopaev, D., Reunanen, P. Mönkkönen, M., 2015. Managing a boreal forest landscape for providing timber, storing and sequestering carbon. Ecosyst. Serv. 14, 179-189.

Trossero, M., Drigo, R., 2004. Wood fuels. In: Trinnaman, J., Clarke, A. (Eds.), Survey of Energy Resources. Elsevier Science, Oxford, pp. 247-266.

Uliczka, H., Angelstam, P., Roberge, J.M., 2004. Indicator species and biodiversity monitoring systems for non-industrial private forest owners: is there a communication problem? Ecol. Bull. 379-384.

Vanwambeke, S.O., Meyfroidt, P., Nikodemus, O., 2012. From USSR to EU: 20 years of rural landscape changes in Vidzeme, Latvia. Landsc. Urban Plan. 105, 241-249.

Villard, M.-A., Taylor, P.D., 1994. Tolerance to habitat fragmentation influences the colonization of new habitat by forest birds. Oecologia 98, 393-401.

Williams, M., 2003. Deforesting the Earth: from Prehistory to Global Crisis. Chicago University Press, Chicago.

Winkler, H., Christie, D.A., Nurney, D., 2010. Woodpeckers. A Guide to the Woodpeckers, Piculets and Wrynecks of the World. A \& C Black Publishers Ltd, London.

With, K.A., Crist, T.O., 1995. Critical thresholds in species' responses to landscape structure. Ecology 76, 2446-2459.

Woodhouse, S., Lovett, A., Dolman, P., Fuller, R., 2000. Using a GIS to select priority areas for conservation. Comput. Environ. Urban Syst. 24, 79-93.

Worster, D., 1994. Nature's Economy: a History of Ecological Ideas. Cambridge University Press, Cambridge.

Zinovskij, V.I., 2006. Statisticheskij Sbornik “Region Respubliki Belarus. Minstat Respubliki Belarus, Minsk. 